\title{
Tax Residence and the Mobility of Companies in the European Union: The Desirable Harmonization of the Tax Connecting Factors
}

\author{
Aurora Ribes Ribes*
}

\begin{abstract}
This article emphasizes the problems caused by the lack of harmonization of the connecting factors in order to determine the fiscal residence of companies. In practice, the current discussion on application of the freedom of establishment for companies has focused on the transfer of their seat within the EU. But no unifying or harmonizing measures has yet been adopted at the European level.

This absence of regulation enables EU Member States to establish their own criteria, which obviously may vary depending on each national legal system. In our view, notwithstanding the existing case law, the intervention of the European legislator is required in order to solve either the tax evasion, or the international double taxation that could arise from a corporate mobility situation. Undoubtedly, tax harmonization of the connecting factors would improve the economic integration in the EU, without significant interference in the fiscal sovereignty of the Member States.
\end{abstract}

\section{TAX REsidence AND THE FREEDOM OF ESTABLISHMENT FOR COMPANIES IN THE EUROPEAN UNION: THE LACK OF HARMONIZATION OF THE CONNECTING FACTORS}

The internationalization of business that has taken place in a globalized world in recent decades has brought about a significant increase in the mobility of companies. Notwithstanding the economic integration that the European Union (hereinafter, EU) implies, domestic tax laws still prove to be an important obstacle to the freedom of establishment of companies in the EU.

The convenience of harmonizing the tax connecting factors applied by EU Member States is especially compelling in the corporate tax field since the tax residence concept is interpreted and determined independently by each Member State. The EU law does not define the circumstances under which an entity is considered resident in a territory. This absence of regulation enables EU Member States to establish their own criteria, which means that these criteria may vary depending on each national legal system. In this sense the European Court of Justice (hereinafter, ECJ) has already held that 'in the absence of any unifying or harmonizing Community measures, Member States retain the power to define, by treaty or unilaterally, the criteria for allocating their powers of taxation, $(\ldots)^{\prime} .{ }^{1}$

The autonomous exercise of this national competence by each Member State is a cause of conflict and the freedom of establishment of companies may be distorted as a result of the lack of coordination of the different domestic legal systems. Although the absence of harmonization measures ${ }^{2}$ has been mitigated by the ECJ, this is a provisional situation and obviously requires intervention by the Community legislator in order to unify the connecting factors applicable in this ambit. The diversity of the current criteria envisaged in the different tax systems has caused great uncertainty among economic agents, not to mention the possibility of international double taxation or even the risk of tax evasion, that undoubtedly has a negative effect on companies and makes it difficult to attain some of the goals enshrined in the Treaty on the Functioning of the European Union (hereinafter, TFUE).

Furthermore, Member States refer to double taxation conventions in order to determine the tax residence of a company that carries out its activity in more than one

\section{Notes}

Tax Law Professor. University of Alicante (Spain).

Judgment of the ECJ of Sep. 7, 2006, Case C-470/04, Nv. Inspecteur van de Belastingdienst Oost/kantoor Almelo, para. 44. See also, in the same line: Judgment of the ECJ of May 12, 1998, Case C-336/96, Mr. and Mrs. Robert Gilly and Directeur des services fiscaux du Bas-Rhin; and the Opinion of the General Advocate Mr. Geelhoed in the Case Act Group Litigation (Judgment of the ECJ of Dec. 12, 2006, Case C-374/04, Test Claimants in Class IV of the ACT Group Litigation v. Commissioners of Inland Revenue), para. 52.

This question is under study by the European Commission, as shown in the: 'Communication from the Commission to the Council, the European Parliament and the Economic and Social Committee, Towards an Internal Market without Tax Obstacles - A Strategy for Providing Companies with a Consolidated Corporate Tax Base for their EU wide activities', COM (2001) 582 final, Oct. 23, 2001. In the Communication, the Commission identified the necessity of coordinating the concept of the fiscal residence of companies in the EU and proposed the approval of general criteria and guidelines that would approximate the laws of the Member States with regard to the fiscal residence of companies. 
State. This practice alleviates the effect of double taxation motivated by dual residence, but does not completely eliminate the problem. Consider, for instance, triangular cases: the plurality of DTTs involved implies that different connecting factors are applied in order to establish the residence of a company. ${ }^{3}$

For these reasons, it is evident that the current regulations should be harmonized at the European level. In our view, most of the problems facing companies will be solved if Member States apply the same criterion to determine the tax residence.

\section{RESIDENCE OF COMPANIES UNDER DOMESTIC CORPORATE TAX LAW}

\section{I Criteria Applied to Determine Corporate Tax Residence in the Domestic Laws of the EU Member States 4}

\section{I.I Incorporation Doctrine versus seat Doctrine}

As is known, in the EU there are two different approaches for determining the tax residence of companies: ${ }^{5}$ the place of incorporation theory and the real seat theory.

According to the first model, the residence of a company and, thus, the applicable law, is determined by where the company is incorporated or formally registered. The most important factor in this theory is the will of the companies' owners, as they can choose the country in which the company is to be registered (lex societatis). However, it should be remembered that only the national laws of each country can determine the tax residence of a company and consequently consider it liable in its jurisdiction.

The United Kingdom, Denmark, Greece, Sweden, the Netherlands and Switzerland, among others, apply this model, which is based on a juridical circumstance. In contrast to the real seat theory, the place of effective management or the place where the business activities are carried out is irrelevant. Certainly, this formal doctrine, which can adopt an individual or cumulative character, entails both advantages and disadvantages. ${ }^{6}$ Its simplicity and the minor disparity in criteria can be seen as advantages. Indeed, the fact that merely registering a company automatically determines the law applicable obviously implies great legal certainty and, hence, better protection of third parties. For this reason, the ECJ has pronounced in favour of this doctrine, in Überseering and Inspire Art, as a valid approach to avoid obstacles to the freedom of establishment of companies in the EU.

On the other hand, the fact that this model makes it possible to incorporate companies abroad for the sole purpose of avoiding the corporate tax law of the State where its registered office is located has been criticized. It should be noted, however, that the concept which can be easily manipulated is not the criterion of incorporation but the concept of residence ${ }^{7}$ (because of its effects: the liability of residents to pay tax on their worldwide income). In this sense, the real seat model can also be manipulated in order to pay a less onerous tax rate.

Besides, the real seat theory is based on factual circumstances. According to this model, for taxation purposes a company is resident in the country in which its primary centre of interests and business activities are located. Taking this idea as a starting point, the real seat can be described as the requisite imposed in order to determine which companies are resident, or as an additional element to take into account when determining the residence of a company. This model has also been supported by the ECJ, which defined it as a link connecting the company with the legal system of a particular State. ${ }^{8}$

The main problem with this theory is how the expression 'real or effective seat' is interpreted, especially because the Member States have adopted different criteria to establish the factual circumstances that imply the existence of a real seat. Whereas some authors identify it with the place of central administration, others consider it to be the primary centre of business activities (lieu d'explotation). In practice, most of the Member States applying this model (France, Germany and Spain, among others) choose the first option, but require that the place of incorporation of a company coincides with the State where the central management and control of the company is located. This last measure reinforces the economic connection with the territory. A good example of this is the place of effective management criterion, set out both in Spanish domestic law and in the double tax treaties. Nevertheless, this criterion is currently under discussion because of its technical deficiencies.

Although this criterion was initially adopted as the best one, rather than the formal criteria (place of incorporation and registered office) which are subordinated to the will of

\section{Notes}

E. González Sánchez, Residencia fiscal y libre establecimiento de las empresas en la Unión Europea, 61 (I) Revista vasca de Administración Pública 61 and 62 (2001).

M. Hofstätter \& P. Plansky (eds.), Dual Residence in Tax Treaty Law and EC Law (Linde Verlag Wien 2009).

L. De Broe, Maisto, G. (ed.): Residence of Companies under Tax Treaties and EC Law, EC and International Tax Law Series, 5, at 95-120 (Guglielmo Maisto Series ed., International Bureau of Fiscal Documentation 2009); J.F. Avery Jones, Corporate Residence in Common Law: The Origins and Current Issues, 121-182 (Maisto, G. ed.: 'Residence (....)'. supra).

F.J. Garcimartín Alférez, Derecho de sociedades y conflictos de leyes: una aproximación contractual, 52 et seq. (Edersa, Madrid, 2002).

O. Jacobs, C. Spengel \& A. Schäfer, ICT and International Corporate Taxation: Tax Attributes and Scope of Taxation, 31 Intertax no. 6-7, 226 (2003).

Judgment of the ECJ of Jan. 28, 1986, Case 270/83, European Commission v. France, para. 18. 
the companies' owners, the place of effective management has proved to be a very problematic criterion. Indeed, its factual nature and, consequently, extensive and indefinite character have led to conflicts of interpretation and frequent overlapings between national legal systems when companies with a complex structure or international interests are involved.

\subsubsection{Different Tax Connecting Factors for Companies in the EU Member States}

The United Kingdom was the first country to adopt, during the nineteenth century, a criterion similar to the place of effective management. In accordance with the expression 'the common law test of central management and control', companies are resident in the place where their central management and control is located. The origin of this criterion dates back to the period when commercial transactions between the United Kingdom and the Commonwealth countries were on the rise. Although a number of companies were incorporated in the territory of the Commonwealth, their effective management was exercised from London. Consequently, the UK Revenue9 declared that a non-UK incorporated company is deemed to be resident in the United Kingdom for tax purposes when it mainly operates from this territory. ${ }^{10}$

At the beginning it was easy to determine the place where the central management and control of the companies was located. As a general rule, it coincided with the place where the directors met to adopt company decisions. However, improvements in means of transport and other circumstances made it possible to manipulate this criterion ${ }^{11}$, so the Courts ${ }^{12}$ were called on to solve case by case problematic questions, with the subsequent uncertainty this involved. Despite several judgments of the Courts, ${ }^{13}$ the criteria to determine this control, which until 1984 was the sole connecting factor to establish corporate residence, was not defined.
By virtue of Article 66(1) of the Finance Act 1988, the UK changed its regulation by introducing the so-called 'statutory test of the place of incorporation'. Since then, a UK incorporated company has been deemed to be resident in the UK for tax purposes, regardless of the place where its primary centre of business activities is located. ${ }^{14}$ This rule is equally applicable to the Societas Europaea. ${ }^{15}$

In balance, under UK tax law, a company's residence can be established by reference to either the common-law test of central management and control or the statutory test of place of incorporation. As stated above, under the statutory test, as from 15 March 1988, a UK incorporated company is deemed to be resident in the United Kingdom for tax purposes (this is subject to the qualification rule introduced in the Finance Act 1994). ${ }^{16}$ At present, ${ }^{17}$ the common-law test of central management and control is only relevant to offshore or non-UK incorporated companies. It is directed at the highest level of control of the business of a company. In broad terms, it looks at how and where the directors exercise their powers and whether this conduct in fact leads to the exercise of central management and control. If the directors' powers are usurped by a manager or a controlling shareholder, then their conduct and residence status is also relevant. This means that in certain circumstances, the separate legal personality of a company is 'looked-through' and the conduct and residence of its directors and/or managers and/or controlling shareholders is relevant to the company's residence. Whether or not a company is resident in the United Kingdom under this test is a question of fact.

Concerning the Austrian ${ }^{18}$ corporate income tax law, companies are subject to unlimited tax liability if either their effective management or legal seat is located in Austria. In the hypothesis that a company has its seat and its effective management in two different countries, the place of effective management prevails in determining the company's residence.

The seat is usually determined by law, contract, articles of association or the like. Otherwise, the seat coincides

\section{Notes}

9 The generic expression 'UK Revenue' is used to refer to the UK Inland Revenue, as it was known until 2005, and Her Majesty's Revenue and Customs (HMRC), as it is called now.

10 De Beers Consolidated mines Limited v. Howe, [1906] AC 455, 458, (1906) 5 TC 198, 212.

11 E. González Sánchez, El concepto de residencia fiscal de las entidades en el ámbito de la Unión europea: la necesidad de su reforma como punto de conexión entre las Administraciones Tributarias y los contribuyentes, 10 Nueva Fiscalidad 3 (2004).

12 Swedish central Railway Co Ltd v. Thompson, HL 1925, 9 TC 342; [1925] AC 495.

13 Calcutta Jute Mills Co Ltd v. Nicholson, (1876) 1 TC 83; Cesena Sulphur Co Ltd v. Nicholson, (1876) 1 TC 88; Bullock versus Unit Construction Co Ltd, (1959) 38 TC 712, and Re Little Olympian Each Ways Ltd, [1994] 4 All ER 561 (Lord Lindsay)

14 Memec v. IRC, Simon's Tax Cases, 1996, 1337

15 L.A. Martínez Giner, Fiscalidad de la Sociedad Anónima Europea (Instituto de Estudios Fiscales, Madrid 2005).

16 Section 249 Finance Act 1994

17 D. Sheridan, The Residence of Companies for Taxation Purposes, 3 British Tax Review 78 (1990); C. Panayi, Country Report: United Kingdom, 817-854 (Maisto, G. ed.: 'Residence (...)'. supra). The UK Revenue distinguishes now three administrative levels in a company: the shop floor, the head office and the place where the central policy core of the whole enterprise is decided.

18 K. Simader, Country Report: Austria, 339-374 (Maisto, G. ed.: 'Residence (...)'. supra). H. Zöchling, C. Hasenauer, W. Wiesner \& C. Unger, Taxation of Companies in Austria, 58 Bull. Intl. Tax. no. 8, 399 and 400 (2004). 
with the place of effective management. Multiples seats are not possible. The place of effective management is located at the centre of the business management. It follows from the term 'centre' that a company can only have one place of effective management. In general, the place of effective management will be located where the seat is established. However, seat and place of effective management need not necessarily coincide. Contrary to the statutory seat, the location of the place of effective management depends on how the company is actually organized; it has to be determined based on actual facts. A three-step approach is usually taken to determine where a company has its business management centre: first, the crucial decisions are determined; second, the persons who make these decisions are identified; and, third, the location of such persons is ascertained. The problem arises when the Courts recognize both the importance of general decisions and of the decisions on day-to-day management. Which kinds of decisions are decisive will depend on the company's business activity, which again means a great uncertainty.

On the other hand, a company is a resident of Belgium ${ }^{19}$ if it has its registered office, its principal establishment or its seat of management or administration in Belgium. By contrast, a company is not a resident of Belgium if none of these connecting factors is based in Belgium. There is very little Belgian case law dealing with the interpretation of these concepts. However, taking into consideration the existing case law, it can be affirmed that the factual circumstances of each particular case must be analyzed in order to determine the place where the company is effectively managed.

With regard to the first criterion, registered office is a formal concept: it is the official seat. As Belgian tax law is based on the real seat theory, the registered office is a rebuttable presumption of fiscal residence. It is up to the company to refute this presumption by demonstrating that its place of effective management is situated elsewhere. By contrast, the principal establishment is not a formal but rather a factual concept; it is the place from where the company is managed and controlled. The elements taken into account when determining the location of the principal establishment are the place where the company's management has its offices, where the general meetings of shareholders are held, where the board of directors meets, etc. When the registered office and the principal establishment are situated in two different
States, the company's residence is determined by the location of the principal establishment.

The company's seat of management or administration constitutes the last criterion and seems to refer to two different concepts, although both are synonymous and coincide with the principal establishment: the seat of management and the seat of administration. It is not clear why the legislator included this additional criterion. Most likely, the reference to the management or administration of the company serves to clarify the term principal establishment, indicating that the company's residence is determined by the location of its principal establishment of management or administration and not its principal exploitation establishment or its principal trading establishment.

The French ${ }^{20}$ system provides that companies are subject to tax on income derived from any business that is carried on in France. The concept of residence is absent from the sections of the French tax code dealing with corporate income taxation. However, since the territoriality regime is based on the source of income rather than on the residence of the beneficiary of the income, the concept of residence is in principle irrelevant.

Nevertheless, the guidelines adopted by the French Tax Administration as well as the case law do not apply this principle strictly. ${ }^{21}$ There is in fact a presumption that the income received by a French corporation is in principle taxable in France unless the company has a permanent establishment abroad. On the other hand, a company whose registered office is located abroad is only deemed to be resident in France if it has a permanent establishment in French territory. ${ }^{22}$ This presumption is based on the fact that, at first glance, the general management is located at the seat. The consequence of this presumption is that all the profits that are not attributed to a specific establishment must be allocated to the seat by default.

In Germany, ${ }^{23}$ a company is subject to unlimited corporation tax liability if it has a place of management or its seat within domestic jurisdiction. These criteria must be fulfilled alternatively rather than cumulatively. In contrast to the British literature and case law, German scholars identify the criterion of place of management (Ort der Geschäftleitung) with the international criterion of place of effective management. In this respect, it can be affirmed that the concept of Ort der Geschäftleitung refers to the place where the central management of the company is located; consequently, the tax residence of multinational

\section{Notes}

19 N. Bammens, Country Report: Belgium, 375-406 (Maisto, G. ed.: 'Residence (...)'. supra).

20 H. Lehérissel, The Tax Residence of Companies, 39 Eur. Tax. J. no. 4, 157-160 (1999); N. De Boynes, Country Report: France, 441-460 (Maisto, G. ed.: 'Residence (...)'. supra).

21 J. Anderson, French Headquarters and Investment Incentives: A Comparative Analysis, 49 BIFD no.9 417 (1995); Long, Y., Corporate beadquarters in France, 19 Intertax no.8-9, 421 et seq. (1991).

22 P. Juilhard, Corporate Income Tax: Recent Developments in the French Territorial Approach, 49 BIFD no. 3, 107 et seq. (1995).

23 J. Englisch, Country Report: Germany, 461-518 (Maisto, G. ed.: 'Residence (...)'. supra). 
corporations is the place where the most important decisions of the company are adopted, and not where they are applied.

A company is resident in Spain provided that one of the following conditions ${ }^{24}$ is met: a) It is incorporated under Spanish law; b) Its legal seat is located in the territory of Spain; c) Or its place of effective management is in Spain. The Spanish tax authorities may deem a company located in a tax haven or a low-tax territory to be resident in Spain if the majority of its assets consist of immovable property located in Spain, or rights on such immovable property, unless the company is based in such territory for valid economic reasons other than the mere management of securities. $^{25}$

According to the Italian system, ${ }^{26}$ companies and other entities are resident for tax purposes if their legal seat, place of management or main object of their business activity is in Italian territory for most of the taxable period. It must be kept in mind that, for a company or entity to be deemed resident in Italy, only one of the criteria needs to be met. As previously noted, the criterion of legal seat is based on a formal element; for this reason, it has been criticized since it may not properly ensure that taxes are levied in accordance with the ability to pay principle envisaged in the Italian Constitution. Such principle would indeed require a more permanent and effective link between the taxpayer and Italian territory.

Besides, the place of management is generally understood to be the place at which the management and control functions of the company are effectively carried out, and since it is based on factual elements, this criterion triggers a number of uncertainties. The main object of the business of the entity, which constitutes the third criterion, must be determined according to the law, the articles of association or the statutes of the company. Should no such elements exist, the main object will be ascertained by taking into account the activity effectively carried on by the company. The lack of any reference to a personal element explains why the Italian Courts have always adopted a substance over form approach in order to consider the effective seat as the place where the essential activities are in fact carried on.

With regard to the Swedish system, ${ }^{27}$ a company is considered to be resident in Sweden if it is registered in the 'Swedish Companies Registration Office', irrespective of the State where the place of effective management is based or where the shareholders have their residence.

The basic rule in order to determine the tax residence of a company in the Netherlands ${ }^{28}$ is envisaged in Article 4(1) of the General State Taxes Act as the 'all-facts-andcircumstances' test. This article sets out that: 'The place of residence of an individual or an entity is determined according to circumstances'. Needless to say, this rule can be characterized as an 'open norm', which means that its interpretation is to the greatest extent possible left to the Courts and thus the latter may tailor its application on a case-by-case basis. In other words, how the all-facts-andcircumstances test should be applied in practice is governed by case law.

According to long-standing case law, the place of effective management of a company is normally decisive in determining its place of residence under the above test. Factors that may serve to establish the place of effective management include, for instance: the place of residence of its (executive) directors; the place where board meetings take place; and the place where the company has its (head) office. In contrast to Austria, where the Courts have recognized the relevance of both types of management (key management and day-to-day management), in the Netherlands the expression 'effective management' generally refers to the principle management of the company.

On the other hand, in 1995 the Netherlands introduced the so-called incorporation fiction. From this point of view, a company registered under Dutch law, regardless of its place of effective management, is considered to be resident in the Netherlands. This presumption has been the subject of debate ${ }^{29}$ because of its controversial character from the European and international perspective, since it involves the risk of direct discrimination based on a company's nationality.

The tax connecting factors currently applied by EU Member States in order to determine the tax residence of companies are the following: ${ }^{30}$

\begin{tabular}{|c|l|}
\hline EU Member States & Tax connecting factors \\
\hline Austria & $\begin{array}{l}\text { Legal seat or place of } \\
\text { effective management. }\end{array}$ \\
\hline
\end{tabular}

\section{Notes}

24 L.A. Martínez Giner, Country Report: Spain, 753-793 (Maisto, G. ed.: 'Residence (...)'. supra); J.M. Almudí Cid, Los sujetos pasiuos en el Impuesto sobre sociedades (El Impuesto sobre sociedades (AAVV, El Impuesto sobre sociedades y su reforma para 2007), 75 et seq. (VVAA, Thomson-Civitas 2006).

25 B. García Carretero, La presunción de residencia fiscal introducida por la Ley 36/2006 de medidas de prevención del fraude fiscal, con relación a las entidades radicadas en territorios de nula tributación o paraísos fiscales, 12 Quincena Fiscal 20 (2008).

26 M. Tenore, 'Country Report: Italy', 519-550 (Maisto, G. ed.,: 'Residence (...)'. supra); G. Campolo, Deemed Italian Tax Residence for Foreign Holding Companies, 47 Eur. Tax. J. no. 1, 55-57 (2007).

27 Chapter 6, sec. 3IL of the Swedish Corporate Tax.

28 R. De Boer, Country Report: The Netherlands, 551-602 (Maisto, G. ed.: 'Residence (...)'. supra).

29 C. Van Gennep, Dual-resident companies: the second sentence of article 4(1) of the OECD Model Convention of 1977, 31 Eur. Tax. J. no. 5, 141 et seq. (1991).

30 O. Van Boeijen-Ostaszewska (ed.), European Tax Handbook 2011 (IBFD 2011). 


\begin{tabular}{|c|c|}
\hline EU Member States & Tax connecting factors \\
\hline Belgium & $\begin{array}{l}\text { Legal seat, main } \\
\text { establishment or place of } \\
\text { effective management. }\end{array}$ \\
\hline Bulgaria & $\begin{array}{l}\text { Place of incorporation; } \\
\text { European Companies and } \\
\text { European Cooperative } \\
\text { Societies registered in } \\
\text { Bulgaria and having their } \\
\text { head office there. }\end{array}$ \\
\hline Cyprus & $\begin{array}{l}\text { Place of management and } \\
\text { control of the company. }\end{array}$ \\
\hline Czech Republic & $\begin{array}{l}\text { Legal seat or place of } \\
\text { management of the } \\
\text { company. }\end{array}$ \\
\hline Denmark & $\begin{array}{l}\text { Place of incorporation or } \\
\text { place of management of } \\
\text { the company. }{ }^{32}\end{array}$ \\
\hline Estonia & Place of incorporation. \\
\hline Finland & Place of incorporation. \\
\hline France & $\begin{array}{l}\text { Legal seat or place of } \\
\text { effective management of } \\
\text { the company. }\end{array}$ \\
\hline Germany & $\begin{array}{l}\text { Legal seat or place of } \\
\text { management of the } \\
\text { company. }\end{array}$ \\
\hline Greece & Place of incorporation. ${ }^{33}$ \\
\hline Hungary & $\begin{array}{l}\text { Place of incorporation or } \\
\text { place of management of } \\
\text { the company. }\end{array}$ \\
\hline Ireland & Place of incorporation. ${ }^{34}$ \\
\hline Italy & $\begin{array}{l}\text { Place where, for the } \\
\text { greater part of the year, the } \\
\text { company has its legal seat, } \\
\text { place of effective } \\
\text { management or main } \\
\text { business purpose. }\end{array}$ \\
\hline
\end{tabular}

\begin{tabular}{|c|c|}
\hline EU Member States & Tax connecting factors \\
\hline Latvia & Place of incorporation. \\
\hline Lithuania & Place of incorporation. \\
\hline Luxembourg & $\begin{array}{l}\text { Legal seat or place of } \\
\text { effective management of } \\
\text { the company. }\end{array}$ \\
\hline Malta & $\begin{array}{l}\text { Place of incorporation. } \\
\text { Companies that are not } \\
\text { incorporated in Malta are } \\
\text { considered to be resident } \\
\text { therein when the control } \\
\text { and management of their } \\
\text { business are exercised in } \\
\text { Malta. }{ }^{35}\end{array}$ \\
\hline Poland & $\begin{array}{l}\text { Legal seat or place of } \\
\text { management of the } \\
\text { company. }\end{array}$ \\
\hline Portugal & $\begin{array}{l}\text { Legal seat or place of } \\
\text { effective management of } \\
\text { the company. }\end{array}$ \\
\hline Romania & $\begin{array}{l}\text { Place of incorporation or } \\
\text { place of effective } \\
\text { management of the } \\
\text { company. }{ }^{36}\end{array}$ \\
\hline Slovak Republic & $\begin{array}{l}\text { Legal seat or place of } \\
\text { effective management of } \\
\text { the company. }\end{array}$ \\
\hline Slovenia & $\begin{array}{l}\text { Legal seat or place of } \\
\text { effective management of } \\
\text { the company. }\end{array}$ \\
\hline Spain & $\begin{array}{l}\text { Place of incorporation, or } \\
\text { place of the legal seat or of } \\
\text { the effective management } \\
\text { of the company. }\end{array}$ \\
\hline Sweden & Place of incorporation. \\
\hline
\end{tabular}

\section{Notes}

31 Registration in Cyprus is not decisive. Resident companies are taxed on their worldwide income, while non-resident companies are taxed on their Cyprus-source income only. A company which is not resident in Cyprus but has a permanent establishment there may opt to be treated as a resident company in order to benefit from a worldwide set-off of losses.

32 For the place of management test, the location of the day-to-day management is normally decisive.

33 Entities incorporated in Greece are resident in Greece for tax purposes. Entities incorporated outside Greece but effectively managed from Greece are in principle deemed as tax residents of Greece, although Greek tax authorities have not applied the effective management criterion so far.

34 This rule does not apply to companies carrying on, or related to companies carrying on, a trade in Ireland, provided that they are either under direct or indirect control of persons resident, or traded on a recognized stock exchange, in a EU Member State or in a tax treaty country. Previously, the common-law test for corporate residence depended on where the central management and control of the company took place. W. Cunningham, Irish-incorporated Companies - New Residence Rules, 53 Bull. Intl. Tax. no. II, $476-480$ (1999)

35 A. Zarb \& P. Portelli, Malta. Company Taxation Update, 4I Eur.Tax. J. no. 5, 193-199 (2001).

36 European Companies and European Cooperative Societies are considered to be resident in Romania if they have their registered office in this State and are incorporated under EU law. 


\begin{tabular}{|c|l|}
\hline EU Member States & Tax connecting factors \\
\hline The Netherlands & Place of incorporation. ${ }^{37}$ \\
\hline United Kingdom & Place of incorporation. ${ }^{38}$ \\
\hline
\end{tabular}

\subsection{Criteria Applied to Determine Corporate Tax Residence in the Domestic Laws of other States}

The diversity of criteria ${ }^{39}$ likewise constitutes the most relevant note concerning how other States that are not members of the EU determine the tax residence of companies. In Australia, ${ }^{40}$ for example, three alternative statutory methods are applied: the incorporation test, the central management and control test and the voting power control test. The latter criterion is intended to apply to companies whose shareholders controlling the voting power of the company are residents of Australia in order to ensure that these resident shareholders, who receive taxfree dividends arising from profits not taxed outside Australia, are taxable on those dividends.

In other countries, such as Canada ${ }^{41}$ or South Africa, ${ }^{42}$ two tests are applied alternatively in order to determine the tax residence of companies. In the first case, a corporation is considered to be resident in Canada if it was registered under Canadian law (place of incorporation test), or if it is mainly controlled from this territory (central management and control test). The place of incorporation test is also envisaged in South Africa, where it operates alternatively with the place of effective management criterion.

Under the Swiss system, ${ }^{43}$ legal entities (which include corporations and limited liability companies) are considered tax residents if their registered office or place of effective management is located in Switzerland. As commented above, in an international context conflict may arise in the following cases: when a company is incorporated abroad but has its effective management in Switzerland; when a company is incorporated in Switzerland but has its effective management abroad. Under Swiss law, the place of effective management is the determining factor and it is not necessary to demonstrate that the seat abroad is a pure formality. In the second hypothesis, the company is also considered a Swiss resident and subject to full taxation in Switzerland; in this case, the criterion of the seat is decisive. Obviously, some of these situations may give rise to double taxation conflicts that can only be solved by DTTs.

Finally, it is important not to lose sight of the American system, ${ }^{44}$ where the terms applied in this ambit are not 'resident' or 'non-resident', but 'domestic' and 'foreign'. These terms, as defined in the Internal Revenue Code, are not interchangeable with 'resident' and 'non-resident', which are the relevant notions affecting taxation of individuals. On the whole, a domestic corporation is what would be considered a resident corporation in other tax regimes; and, similarly, a foreign corporation would be considered a non-resident corporation. A domestic corporation is one that is created or organized in the United States or under the laws of any state; and, a foreign corporation is a company which is not domestic. There are no other common law or statutory tests that determine residence based on other factors such as place of effective management. The test is mechanistic and generates a clear result: a company is taxed as a domestic corporation, and is therefore subject to worldwide taxation, if it is organized under the laws of one of the US states

\section{Final Remarks in the Light of the eCJ CASE LAW AND THE REGULATION ON THE STATUTE FOR A EUROPEAN COMPANY}

As is known, no significant progress has been made in this field in recent decades. The tax connecting factors used by EU Member States to determine the residence of companies and, therefore, their tax liability are not sufficiently coordinated in this area.

The place of management, the place where the company's main activity is carried out, the place of central management and control, the real seat, the place where the company has its head office, ${ }^{45}$ the place of effective

\section{Notes}

37 In the case of companies incorporated under foreign law, the place of residence of a company is to be determined according to the circumstances, the most important being the place where the company is effectively managed.

38 Companies not incorporated in the United Kingdom are resident there if the central management and control takes place in the United Kingdom. The decisive element is the place where the board of directors meets or where the company's policy decisions are made, rather than the day-to-day management. The tax authority (HMRC) takes a substantive view of central management and control, tending to look at the de facto management of the company, and where it is located.

39 International Fiscal Association, The Fiscal Residence of Companies, in Cahiers de Droit Fiscal International vol.LXXIIa, premier sujet, (Kluwer International Law 1987); International Fiscal Association, Recognition of Foreign Enterprises as Taxable Entities, in Cahiers de Droit Fiscal International vol.LXXIIIa, premier sujet, (Kluwer International Law 1988).

40 M. Dirkis, Country Report: Australia, 311-338 (Maisto, G. ed.: 'Residence (...)'. supra).

41 K. Brooks, Country Report: Canada, 407-440 (Maisto, G. (ed.): 'Residence (...)'. supra).

42 J. Hattingh, Country Report: South Africa, 603-752 (Maisto, G. ed.: 'Residence (...)'. supra).

43 J.F. Maraia, Country Report: Switzerland, 795-816 (Maisto, G. ed.: 'Residence (...)'. supra).

44 Y. Brauner, Country Report: United States, 855-888 (Maisto, G. ed.: 'Residence (...)'. supra).

45 This criterion is also applied in Korea, Japan and China. 
management, the place of residence of its (executive) directors, the place where board meetings take place, the statutory seat of the company and the law under which it was incorporated, the place of residence of the shareholders and/or non-executive board members, the place where the (annual) accounts are drawn up and the place of registration ${ }^{46}$ (e.g., with the chamber of commerce) are just some of the different criteria currently used by EU Member States. Although this multiplicity of connecting factors can be reduced to three: the legal criterion (incorporation and statutory registered office), the economic criterion (place of main activity) and the criterion related to control (central management and control, etc.), the fact is that their application generates important controversies, especially when EU Member States use a combination of such criteria.

Moreover, it should be noted that we have only addressed the definitions of corporate tax residence and not their applications, which may turn out to be diverse and also lead to different solutions. In sum, conflict seems to be unavoidable.

In practice, conflicts have apparently been solved by the ECJ using a different criterion. In comparison to the ECJ's position in the Daily Mail Case, ${ }^{47}$ the line of reasoning followed in Centros, ${ }^{48}$ Überseering ${ }^{49}$ and Inspire $A r t^{50}$ has moved towards a softer approach in order to permit a company to transfer its seat from one Member State to another. On the basis of these ECJ decisions, a group of authors argued that certain national modalities of the company seat principle (especially the strict German approach) were not permitted under the EC Treaty. In fact, it was even affirmed that the ECJ had preferred the place of incorporation theory to the real seat theory.

The prevalence of this latter model in countries like the United Kingdom means that companies incorporated in this State that wish to transfer their place of central management and control to another Member State cannot retain their fiscal residence in the United Kingdom. They would thus have to bear extra taxation that companies that do not move within the EU do not have to bear.

Another disadvantage of the real seat doctrine is that, due to the circumstantial way in which the place of management and control of a company is determined, it is possible for more than one Member State to declare the company tax residence in its territory. On the other hand, the most relevant advantage of the real seat method is that the possibility of tax evasion is minor. A sensu contrario, under the place of incorporation model, companies can be registered in the Member States in which the laws are more favourable and base their central management and control in those where the costs of undertaking their business activities are lower.

In our view, although the freedom of establishment of companies enshrined in the TFEU must prevail, it should also be weighed up in order to avoid undesirable law shopping practices. At present, far from establishing the place of incorporation model as the only possible system, the ECJ has recently incorporated in Cartesio ${ }^{51}$ the European limitation to EU Member States' competence in determining the law applicable to the transfer of a company's seat within the EU.

Of special interest is the examination of this last decision, which has been intensively discussed in the literature. The authors who agree with the ECJ's decision underline that the freedom of establishment is not affected in the case analyzed in Cartesio. From their point of view, the situation in this case differs from the one examined in $\ddot{U}$ berseering where, as is known, a company incorporated and managed in the Netherlands, which afterwards transferred its place of central management and control to Germany (without losing its place of fiscal residence in the Netherlands), was not recognized by German law.

In the opinion of these tax experts, ${ }^{52}$ the ECJ's decision in Cartesio does not mean a reversal of the previous case law as established in Centros, Überseering and Inspire Art. They are considered to be different scenarios, which logically require different solutions. This is also the argument used by the ECJ when it distinguishes between Daily Mail and Cartesio (characterized as 'outbound establishment' or 'moving out' cases), on the one hand, and Centros, Überseering and Inspire Art (characterized by the Court as 'moving in' or 'inbound establishment' cases) on the other.

As a consequence of the ruling in Cartesio, freedom of establishment does not entitle companies to retain the nationality of their home Member State when they transfer their central administration to another Member State. Had the ECJ ruled in the opposite way, it would have been tantamount to declaring that the only connecting factor for companies that is compatible with EC law is the place of incorporation. However, the ECJ has implicitly refused

\section{Notes}

46 This criterion is also applied in Chile and Venezuela.

47 Judgment of the ECJ of Sep. 27, 1988, Case C-81/87, The Queen v. H.M. Treasury and Commissioners of Inland Revenue, ex parte Daily Mail and General Trust plc.

48 Judgment of the ECJ of Mar. 9, 1999, Case C-210/97, Centros Ltd v. Erbvervs- og Selskabsstyrelsen.

49 Judgment of the ECJ of Nov. 5, 2002, Case C-208/00, Überseering BV v. Nordic Construction Company Baumanagement GmbH (NCC).

50 Judgment of the ECJ of Sep. 30, 2003, Case C-167/01, Kamer van Koophandel en Fabrieken voor Amsterdam v. Inspire Art Ltd.

51 Judgment of the ECJ of Dec. 16, 2008, Case C-210/06, Cartesio Oktató és Szolgáltató bt.

52 D. Deak, Outbound Establishment Revisited in Cartesio, 6 EC Tax Rev. 250-258 (2008). 
to make the place of incorporation model the only conflict of law principle prevailing in the EU. ${ }^{53}$

By contrast, the scholars who reject the ECJ's decision in Cartesio adhere to the position maintained by the General Advocate Mr Poiares Maduro. In their view, ${ }^{54}$ the ECJ's distinction between 'inbound' and 'outbound' scenarios is not convincing. Hence, any restriction on this kind of situations is prohibited by the freedom of establishment principle, which must always be interpreted in a broad sense in order to avoid an incongruent application of European law.

On the whole, it can be affirmed that both the legal framework and the case law on transfer of a company's seat within the EU has not substantially changed since 1988. Since this date, far from clarifying the conflict at issue in the Daily Mail Case, the ECJ has initiated an intense debate that is not yet closed.

The option of establishing an entity under European law -that is to say, a Societas Europaea or a European Cooperative Society-, whose seat can be transferred with the subsequent change of applicable law, has not solved the difficulties encountered by companies incorporated under the national laws of Member States. It should be noted that, in this ambit, companies cannot transfer their central management and control within the EU under the same conditions.

On balance, the EU has enacted very little legislation on transfer of the seat of companies. It was only in October 2004, when the Regulation on the Statute for a European Company came into force, that any legislation was passed. The creation of the Societas Europaea was approved on 8 October 2004. ${ }^{55}$ It is a public European Company with a minimum capital of EUR 120,000 divided into shares.

One of the novelties of the Societas Europaea is the flexibility with which it may move its real seat from one Member State to another in order to facilitate cross-border businesses, mergers and group operations. However, this Regulation does not cover tax issues. Thus, even though companies have Societas Europaea status, they are still considered to be national companies for tax purposes. ${ }^{56}$

Concerning the transfer of the seat of a Societas Europaea, the Regulation on the Statute first refers to the national laws of the Member States and, second, establishes that every Societas Europaea must be registered in the Member State in which it has its registered office. ${ }^{57}$ In our opinion, requiring that European Societies have their place of incorporation in the Member State in which they have their real seat obviously limits the freedom of establishment of companies, as transfer of the seat of a European Society may face obstacles created by the national laws of Member States. ${ }^{58}$

As commented above, the current discussion on application of the freedom of establishment of companies has focused on the transfer of the seat of companies within the EU. This is not a problematic question when both the State of residence and the State of source use the same model to define fiscal residence; but if different methods are adopted, two different problems may arise. In the first case, the company would not be taxed in either State; whereas in the second, a situation of international double taxation could arise.

This situation of uncertainty explains the call made by scholars and, in general, by the different legal agents in order to obtain a better legal framework. In our view, the necessary improvement of the current regulation requires reformulation of the connecting factor used to determine the fiscal residence of companies. In this context, González Sánchez ${ }^{59}$ suggested adopting more tangible criteria that prove the existence of a real and effective link between the company and the State in question.

However, according to another proposal, the importance of the corporate residence rules per se is decreasing ${ }^{60}$ and so the residence criterion could be replaced by the criterion of the State of the source. In fact, the group of authors in favour of this thesis underlines that, taking into account the current global context, ${ }^{61}$ the criterion based on residence is not a realistic one and, thus, conclude that

\section{Notes}

53 R. Szudoczky, How Does the European Court of Justice Treat Precedents in Its Case Law? Cartesio and Damseaux from a Different Perspective: Part I, 37 Intertax no. 6/7, 358 (2009).

54 H. Schneeweiss, Exit taxation after Cartesio: the European fundamental freedom's impact on taxing migrating companies, 37 Intertax no. 6/7, 363-374 (2009); A.P. Dourado \& P. Pistone, Looking beyond Cartesio: Reconciliatory Interpretation as a Tool to Remove Tax Obstacles on the Exercise of the Primary Right of Establishment by Companies and other Legal Entities, 37 Intertax no. 6/7, 344 (2009).

55 Council Regulation (EC) No. 2157/2001, of Oct. 8, 2001 on the Statute for a European Company and Directive 2001/86, of Oct. 8, 1986 on workers.

$56 \mathrm{M}^{\mathrm{a}}$.T. Soler Roch, Tax Residence of the SE, 44 Eur. Tax. J. no. 1, 11 (2004); O. Thömmes, EC Law Aspects of the Transfer of Seat of an SE, 44 Eur. Tax. J. no. 1, 22-27 (2004).

57 Article 12(1) of Council Regulation (EC) No. 2157/2001 of Oct. 8, 2001.

58 E. González Sánchez \& J. Franch Fluxá, The transfer of the seat and the freedom of establishment for companies in the European Union: an analysis of ECJ case law and the regulation on the Statute for a European Company, 45 Eur. Tax. J. no. 6, 228 (2005).

59 E. González Sánchez, 'El concepto (...)'. supra, 7 et seq. Although in a previous paper (E. González Sánchez, Residencia fiscal y libre establecimiento de las empresas en la Unión Europea, 61 (I) Revista vasca de Administración Pública 64 (2001)) this author proposed adopting the place of effective management as the sole criterion to determine the tax residence of companies, according to the OECD Model Convention; at present this criterion is being revised by the OECD.

${ }^{60}$ A. Fantozzi, P. Le Gall, K. Van Raad, Y. Brauner \& A, Nikolakakis, Round Table: the Issues, Conclusions and Summing-up?, 900 (Maisto, G. ed.: 'Residence (...)'. supra).

61 D. Gutmann, Globalizzazione e giustizia tributaria, 3 Diritto e Pratica Tributaria Internazionale 701 et seq. (2002). 
this criterion is neither necessary nor sufficient. ${ }^{62}$ Referring to this discussion, Serrano Antón ${ }^{63}$ highlights the fact that most of the national legal systems currently use a combination of these two criteria, as an acknowledgement of the virtuality of the criterion of the source. ${ }^{64}$

In particular, Kemmeren ${ }^{65}$ reinvents the principle of territoriality by designing an 'Origin Based System'. This theory differs from the traditional conception of the aforesaid principle in that the key element is the cause of the income, which must be in the territory of the State in question, and not the links with the territory, so the origin of the income would be irrelevant. In our opinion, the proximity of these theses is so evident that they may even be said to be identical.

Needless to say, the criterion based on the source does not convince a number of authors. Most of the OECD Member States will never be interested in this principle because they are in favour of worldwide income taxation and consider this proposal a utopia. In addition, it has been said that this thesis would mean going against history, which has demonstrated the convenience of taxing in a single State. To sum up, our conclusion is that taking into consideration the current evolution of economic transactions in a globalized world, application of the traditional concepts of residence and source becomes more complex.

Notwithstanding the existing case law, the intervention of European institutions is necessary in order to solve the problem. ${ }^{66}$ In this respect, we can mention the Resolution of the European Parliament of 10 March 2009, which includes recommendations of the Member States concerning the transfer of the seat of a company. ${ }^{67}$ Apart from this, no unifying or harmonizing measure has yet been adopted at the European level.

From our point of view, tax harmonization of the connecting factors would improve the economic integration in the EU without significant interference in the fiscal sovereignty of the Member States. This desirable coordination in the interpretation and application of the concept should be based, in our opinion, on a formal element (incorporation) in conjunction with the effective economic integration of the company in the territory of the State in question. In conclusion, harmonization of tax connecting factors in this ambit still remains a challenge for the EU. However, it will hopefully become a reality in the near future in order to avoid undesirable distortions of the freedom of establishment of migrating companies.

\section{Notes}

62 Against this position: B.J. Arnold, A Tax Policy Perspective on Corporate Residence, 51 Can. Tax J. no. 4, 1.559 et seq. (2003).

63 F. Serrano Antón, Estudios de Derecho Financiero y Tributario en bomenaje al Profesor Calvo Ortega, volume I, 186 (VVAA, Lex Nova 2005).

64 R. Falcón y Tella, Tendencias actuales en los criterios de sujeción al tributo: hacia la territorialidad, 100 Crónica Tributaria 54 (2001).; International Fiscal Association, 'Source and residence: new configuration of their principles', in Cahiers de Droit Fiscal International, vol. 90 a, 2005 Buenos Aires Congress, Sdu Fiscale \& Financiële Uitgevers, The Netherlands.

65 E. Kemmeren, Principle of Origin in Tax Conventions - A Retbinking of Models (Pijnenburg-Dongen 2001).

66 E. González Sánchez, Corporate Tax Harmonisation in the European Union: Harmonisation of the Tax Connecting Factors (Universidad del País Vasco, Servicio editorial, 2005); J. Franch Fluxá, La armonización de la residencia societaria en el ámbito de la fiscalidad empresarial comunitaria, 340 Revista de contabilidad y tributación 5, 8, 37 and 38 (2011).

67 2008/2196 (INI). Date of publication: Apr. 1, 2010 (2010/C 87 E/02). See also: 'Éttude sur le transfert de siège d'une societé d'un État Membre à un autre'. Luxembourg, European Commission, 1993. J. Van Daele, Tax Residence and the Mobility of Companies: Borderline Cases under Private International Law and Tax Law, 51 Eur. Tax. J. no. 5, 190 et seq.(2011). 